\title{
AN OVERVIEW ON "CELLULAR CANNIBALISM" WITH SPECIAL REFERENCE TO ORAL SQUAMOUS CELL CARCINOMA
}

\author{
M. Jain \\ Department of Oral Pathology and Microbiology, Peoples Dental Academy, Bhopal 462037, Madhya Pradesh, India
}

Cellular cannibalism has been defined as a large cell engulfing a slightly smaller one within its cytoplasm. It has been described in various cancers like bladder cancer, breast cancer, lung cancer, gastric cancer, oral squamous cell carcinoma. Cellular cannibalism has been well correlated with anaplasia, tumor aggressiveness, grading and metastatic potential. Present review focuses on significance of cannibalism in relation to cancer with special emphasis on oral squamous cell carcinoma. Key Words: cannibalism, phagocytosis, cancer, oral squamous cell carcinoma.

The term "cannibalism" is derived from Spanish caníbal in connection with alleged cannibalism among Caribs. Also, called as anthropophagy in Greek, i.e., act or practice of humans consuming other humans $[1,2]$. Actually, cannibalism is a common ecological interaction, occurring naturally in variety of species. Although there are different types of cannibalism, size structured cannibalism being the commonest form in which large individual feeds on smaller ones. Cannibalism occurs at cellular level in humans also [3]. Cellular cannibalism (CC) is defined as the ability of a cell to engulf another living cell leading eventually to death of internalized cell [4]. Unicellular organisms as well as single cells from multicellular organism are capable of centering their entire efforts for accomplishing their feeding requirements, which is mandatory for survival. Experiments have revealed two phenomena, namely self-cannibalism (macroautophagy) and xeno-cannibalism, i.e., engulfing and digesting cell siblings as well as cells from the immune system. It has been hypothesized that these two processes could be interrelated, xeno-cannibalism being representing exacerbation of self-cannibalism thus offering prolific survival benefit to cells [5].

\section{CELLULAR CANNIBALISM: HOW IT DIFFERS FROM OTHER CELL-IN-CELL PHENOMENON?}

Entosis. Entosis is a homogeneous cell-in-cell invasion while cannibalism can be either homogeneous or heterogeneous. In entosis, live epithelial cells or tumor cells detach from extracellular matrix and then invade their neighbor cells. Entosis rely on conjugations or adherens junctions and needs Rho and ROCK activities for internalization, suggesting that entosis is an active process and requires actin polymerization [6].

Emperipolesis. Emperipolesis is a heterogenous cell-in-cell invasion in which engulfed cells are hematopoietic. The cells are only temporarily internalized and are not destroyed [1, 2].

Efferocytosis. The recognition and elimination of apoptotic cells by tissue macrophages and non-

Submitted: June 14, 2015.

Correspondence: E-mail: megha.vipin12@gmail.com Abbreviations used: CC - cellular cannibalism; NTCC - neutrophiltumor cell cannibalism; OSCC - oral squamous cell carcinoma. professional phagocytes such as epithelial cells, endothelial cells, fibroblast and neutrophils known as efferocytosis is critical for development, tissue homeostasis and resolution of inflammation. It is different from other types of cell-in-cell phenomena both cytologically and biologically [7].

Phagocytosis. A brief summary of the differences between $\mathrm{CC}$ and phagocytosis is presented in the Table.

Table. Comparison of CC and phagocytosis as two distinct modes of cellin-cell invasion

\begin{tabular}{|c|c|c|}
\hline Characteristics & $\mathrm{CC}$ & Phagocytosis \\
\hline $\begin{array}{l}\text { Nature of mecha- } \\
\text { nism }\end{array}$ & Very calm phenomena & $\begin{array}{l}\text { Very expensive and } \\
\text { dramatic process }\end{array}$ \\
\hline $\begin{array}{l}\text { Type of cells af- } \\
\text { fected }\end{array}$ & Feeds on live cells & $\begin{array}{l}\text { Feeds on dead cells } \\
\text { and toxic materials }\end{array}$ \\
\hline $\begin{array}{l}\text { Mechanism } \\
\text { of action }\end{array}$ & $\begin{array}{l}\text { In this phenomenon, free cell } \\
\text { lay down on the membrane } \\
\text { of cannibal cells and then sud- } \\
\text { denly get into the tumor cells } \\
\text { and gradually degenerate and } \\
\text { dies off }\end{array}$ & $\begin{array}{l}\text { In this process, mac- } \\
\text { rophage, embrace, } \\
\text { surround and engulf } \\
\text { external body through } \\
\text { formation of huge and } \\
\text { long pseudopod }\end{array}$ \\
\hline Type of activity & $\begin{array}{l}\text { Associated with feeding and } \\
\text { is increased in condition of low } \\
\text { nutrient supply. Aimed at sur- } \\
\text { viving in unfavorable condition. } \\
\text { Usually seen in tumor cells }\end{array}$ & $\begin{array}{l}\text { Associated with sca- } \\
\text { venging activity trig- } \\
\text { gered by starvation } \\
\text { in normal cells }\end{array}$ \\
\hline ole of $\mathrm{pH}$ & $\begin{array}{l}\text { Cannibalistic cells are resistant } \\
\text { to low pH. Acidic conditions in- } \\
\text { creases CC }\end{array}$ & $\begin{array}{l}\text { Macrophages usually } \\
\text { dies at low pH }\end{array}$ \\
\hline Role of caveolin-1 & $\begin{array}{l}\text { Caveolae-mediated endocyto- } \\
\text { sis has a key role }\end{array}$ & Not involved \\
\hline $\begin{array}{l}\text { Role of cathep- } \\
\text { sin-B }\end{array}$ & $\begin{array}{l}\text { Overexpression } \\
\text { of cathepsin-B noted }\end{array}$ & Not involved \\
\hline $\begin{array}{l}\text { ole of ligand-re- } \\
\text { eptor interaction }\end{array}$ & $\begin{array}{l}\text { No specific ligand-receptor in- } \\
\text { teraction seen }\end{array}$ & $\begin{array}{l}\text { Protein-protein inter- } \\
\text { action noted }\end{array}$ \\
\hline
\end{tabular}

\section{CELLULAR CANNIBALISM AND CANCER}

$C C$ has been frequently observed in vivo in several benign and malignant tumors including breast carcinoma [8], giant cell carcinoma of lung [9], endometrial stromal sarcoma [10], malignant melanoma [11], gastric adenocarcinoma [12], giant-cell tumor of the tendon sheath [4], lung carcinoma, gall bladder carcinoma [13], giant cell granuloma of the oral cavity [14], salivary duct carcinoma [15], oral squamous cell carcinoma (OSCC) [16-19]. These tumor cells cannibalize their siblings as well as cells from the immune system in order to sustain and defend existing unfavorable conditions within the microenvironment such as hypoxia, lack of nutrition and acidity. 


\section{Cellular cannibalism - morphology and ap- pearance \\ CC in cytological or histological preparation} is manifested as a cell that is contained within another bigger cell with a crescent shaped nucleus (Fig. 1). This particular appearance is attributed to the fact that ingested cell is contained in a big vacuole that pushes the nucleus of cannibalistic cell to the periphery [19]. Owing to such appearance it was described by Leyden in 1904 as "bird-eye cells" [20].

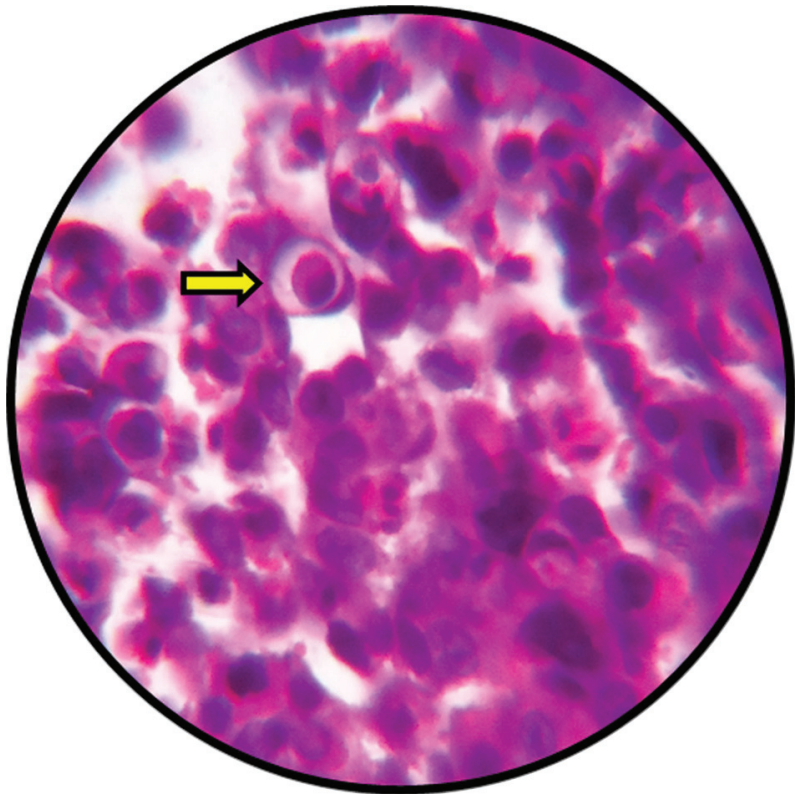

Fig. 1. CC in OSCC. Cannibalistic cell is marked by arrow (haematoxylin and eosin staining, $x$ 40)

\section{Process of cellular cannibalism}

Fig. 2 illustrated the main successive steps of cannibalism as proposed by Brouwer et al. [21]

Cannibalistic cell

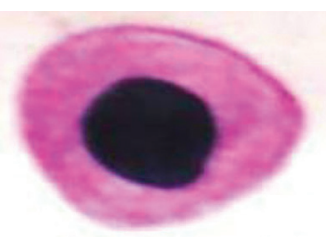

$\downarrow$

Contact of free cell with cannibalistic cell

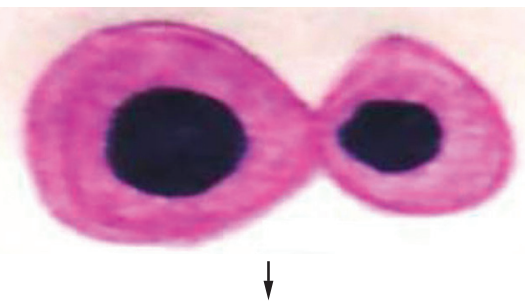

Gradual internalisation of free cell into cannibalistic cell

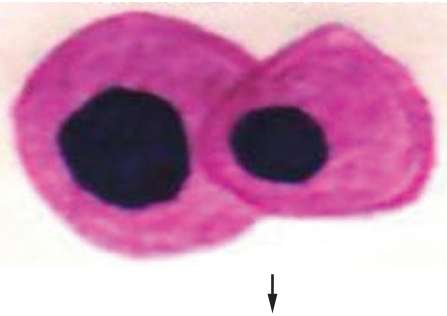

Complete internalisation of free cell into cannibalistic cell leading to crescent shaped nucleus of latter

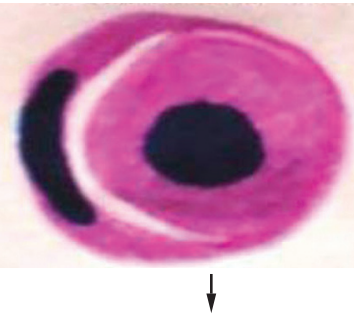

Ultimately, internalised free cell dies off

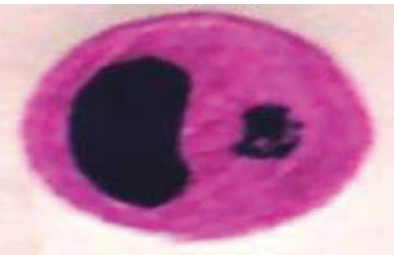

Fig. 2. Schematic representation of the main successive steps of CC

Proposed mechanisms of cellular cannibalism

There is not enough information on the nature and significance of tumor cell cannibalism. Exact mechanism by which tumor cells end up feeding on their sibling cancer cells remain obscure. Following theories have been put forward to explain this event.

(A) Cannibalism occurs so that tumor cells can feed on ingested cells thus obviating tumor cell nutritional deficiencies. Experiments have shown that cannibalism is never observed in serum-free cultures but can be reinduced by serum exposure. Also, ultrastructural examination revealed scanty lysosomal content in cannibalistic cell in comparison with free thus proving that death and disintegration of the interiorized cell is due to starvation rather than the action of lysosomal enzymes [21].

(B) CC may function as a way of eliminating malignant cell thus keeping a check on tumor growth [1]. Brouwer et al. demonstrated that serum dependent cannibalism may contribute to the autodestruction of cells and frequent failure to establish human small cell carcinoma of lung cell lines [21].

(C) Few reports suggested that tumor cells have also taste for other non-sibling cells or immune cells like neutrophils, lymphocytes and erythrocytes and may cannibalise them [11, 12, 15, 16, 22, 23]. Such type of conduct signifies that cannibalistic tumor cells cannot discriminate between tumor infiltrating immune cells and sibling neoplastic cells and thus may use cannibalism as a mechanism of tumor immune escape [1].

\section{Factors regulating cellular cannibalism}

Following factors are known to control phenomenon of cannibalism:

(I) Hunger of the tumor cells/low nutrient supply [1,4].

(II) Tumor microenvironment, i.e., acidity and hypoxia. Carcinogenesis (malignant tumors) results in acidic microenvironment owing to shift in the metabolic pathway which in turn favors selection of certain cell phenotypes that engulf sibling cells and are able to sustain and survive such adverse environment $[4,24$, 25]. This pathogenic mechanism is not relevant to be- 
nign tumors such as peripheral giant cell granuloma and central giant cell granuloma. The giant cells of these pathologies are derived from monocyte-macrophage lineage and resemble osteoclasts thus possessing inherent property of engulfment, which is responsible for cannibalism of stromal tumor cells [26].

(III) Dynamic link between caveolin-1, actin cytoskeleton and ezrin. This network has a key role in formation of cannibalistic vacuole and caveosome and is driving force for cannibalism [4, 27].

(IV) Overexpression of cathepsin B and acidic milieu of lysosomal like vesicles typify cannibalistic cells [4, 22, 27].

Cellular cannibalism: assessment parameters

Cannibalism can be assessed by following parameters [28]:

(I) cellularity of cannibalism - it is semiquantitatively assessed as: $(1+)<5$ cells, $(2+) 5-20$ cells and $\left(3^{+}\right)>20$ cells in each preparation. Jose et al. graded cellularity of cannibalism as Grade I ( $<5$ cells), Grade II (6-15 cells) and Grade III (> 16 cells) [18];

(II) diameter of cannibalism - analyzed using an image analysis system;

(III) chromatin pattern - evaluated as heterochromatin pattern or euchromatin pattern;

(IV) background - assessed as necrosis, isomorphic erythrocytes and dysmorphic erythrocytes;

(V) vimentin reactivity.

\section{Cellular cannibalism as a cancer predictor}

$\mathrm{CC}$ is promising marker of anaplastic grade and invasiveness as well as could serve as a valuable tool in assessing tumor behavior [8]. Barresi et al. [29] suggested that neutrophil-tumor cell cannibalism (NTCC) may be one of the mechanisms favoring tumor growth in gastric micropapillary carcinomas, a tumor histotype characterized by aggressive behavior and poor prognosis. Alok et al. [8] assessed cannibalism in 62 cytologically diagnosed cases of breast malignancies and found that CC was more frequent in high grade tumors, thus considering CC as a marker of anaplasia and aggressive tumor behavior. Study by Bansal et al. [13] illustrated that presence of CC in malignant effusions is more often an indicator of higher tumor stage. Also, cannibalism may act as a reliable predictor of tumor progression from primary to the metastatic site.

Aneuploidy is one of the characteristic features of human cancers and polyploidy being a precursor to aneuploidy during tumor progression. Polyploid cells can originate from cell fusion, endoreplication, and cytokinesis failure. Recently Krajcovic et al. [30] found that cell cannibalism by entosis also leads to polyploidy, as internalized cells disrupt cytokinesis of their engulfing cell hosts. Thus this mechanism can affect cannibalistic cell behavior and could prop up tumor progression by leading to aneuploidy.

Recent studies have demonstrated that horizontal or lateral DNA transfer between eukaryotic cells can occur via uptake of apoptotic bodies and could be attributed for aneuploidy and chromosomal instability responsible for tumor formation and progression [31].

\section{CELLULAR CANNIBALISM AND ORAL SQUAMOUS CELL CARCINOMA}

$\mathrm{CC}$ is one of the typical morphological traits often observed in aggressive malignancies, although it has been demonstrated in certain benign tumors also. It has also been considered as an indicator of aggressiveness, anaplasia and metastatic potential [16, 17]. CC has easily identifiable morphological features under light microscopy without the use of any advanced and expensive molecular techniques. Hence, aggressiveness of the neoplasm can be assessed on a routine basis.

Cellular cannibalism as a prognosticator of oral squamous cell carcinoma

Jose et al. [18] evaluated 20 neck dissection cases of OSCC and found statistically significant correlation between advanced grade of $\mathrm{CC}$ and positive lymph node metastasis. So, the authors concluded that CC can be considered as one of the important parameter to assess an aggressive nature of OSCC.

Sarode SC and Sarode GS (2013) screened 30 cases ( 25 moderately differentiated and 5 poorly differentiated) of OSCC for the presence of cannibalism and found more number of cannibalistic cells in poorly differentiated OSCC compared to moderately differentiated OSCC [17]. No statistical difference between clinical staging of OSCC was found. Also, they have done immunohistochemical analysis with lysozyme and CD68 to validate cannibalism phenomena and demonstrated 10 lysozyme-positive and 5 CD68-positive cases with cell cannibalistic features. Sarode SC and Sarode GS (2014) analysed OSCC for identification of NTCC and found that those OSCC cases which showed extreme NTCC were poorly differentiated and had cervical lymph node metastasis [16]. Thus, NTCC in OSCC could serve as valuable prognostic marker and can foretell biological behavior.

Complex cannibalism and oral squamous cell carcinoma

Sarode et al. [19] studied 5 cases of OSCC and observed bizarre morphological appearance cells where one malignant cell was engulfing the other one and this complex was further engulfed by another cell. So, they proposed a newer terminology to the phenomenon as "complex cannibalism". Maximal number of cannibalistic cells and complex cannibalism was reported in advanced stage and poorly differentiated OSCC. Hence, they concluded that complex cannibalism could be suggestive of highly aggressive biological behavior in OSCC.

\section{CONCLUSION AND FUTURE PERSPECTIVE}

$\mathrm{CC}$ has been proved to be important morphological parameter and has been described in a variety of cancers. It has been well allied with anaplasia, tumor aggressiveness, grading and metastatic potential. Hence it is recommended to screen each cancer specimen for identification of cannibalism to validate its role as a morphological predictor. Literature search fetched up few studies regarding tumor cell cannibalism and OSCC and 
therefore warrants call for future elaborative researches to justify role of $\mathrm{CC}$ as prognosticator of OSCC. Moreover, future studies should also emphasize on underlying biochemical and molecular aspects of CC.

\section{REFERENCES}

1. Sharma N, Dey P. Cell cannibalism and cancer. Diagn Cytopathol 2011; 39: 229-33.

2. Sharma D, Koshy G, Grover S, et al. Cellular cannibalism: an insight. Chrismed J Health Res 2015; 2: 14-8.

3. Fais S. Cannibalism: a way to feed on metastatic tumors. Cancer Lett 2007; 258: 155-64.

4. Fernandez-Flores A. Cannibalism in a benign soft tissue tumor (giant-cell tumor of the tendon sheath, localized type): a study of 66 cases. Rom J Morphol Embryol 2012; 53: 15-22.

5. Malorni W, Matarrese P, Tinari A, et al. Xeno-cannibalism: a survival "escamotage". Autophagy 2007; 3: 75-7.

6. Qian Y, Shi Y. Natural killer cells go inside: entosis versus cannibalism. Cell Resh 2009; 19: 1320-1.

7. Caruso RA, Fedele F, Finocchiaro G, et al. Neutrophiltumor cell phagocytosis (cannibalism) in human tumors: an update and literature review. Exp Oncol 2012; 34: 306-11.

8. Alok M, Singh S, Swarn K, et al. Cell cannibalism as an indicator of anaplasia and tumor aggresiveness in carcinoma breast. J Adv Res Biol Sci 2013; 5: 286-9.

9. Craig ID, Desrosiers P, Lefcoe MS. Giant-cell carcinoma of the lung. A cytologic study. Acta Cytol 1983; 27: 293-8.

10. Hong JS. The exfoliative cytology of endometrial stromal sarcoma in peritoneal fluid. Acta Cytol 1981; 25: 277-81.

11. Lugini L, Matarrese P, Tinari A, et al. Cannibalism of live lymphocytes by human metastatic but not primary melanoma cells. Cancer Res 2006; 66: 3629-38.

12. Caruso RA, Muda AO, Bersiga A, et al. Morphological evidence of neutrophil-tumor cell phagocytosis (cannibalism) in human gastric adenocarcinomas. Ultrastruct Pathol 2002; 26: $315-21$.

13. Bansal C, Tiwari V, Singh US, et al. Cell cannibalism: a cytological study in effusion samples. J Cytol 2011; 28: 57-60.

14. Sarode SC, Sarode GS. Cellular cannibalism in central and peripheral giant cell granuloma of the oral cavity can predict biological behavior of the lesion. J Oral Pathol Med 2014; 43: 459-63.

15. Arya P, Khalbuss WE, Monaco SE, et al. Salivary duct carcinoma with striking neutrophil-tumor cell cannibalism. CytoJournal 2011; 8: 15.
16. Sarode SC, Sarode GS. Neutrophil-tumor cell cannibalism in oral squamous cell carcinoma. J Oral Pathol Med 2014; 43: 454-8.

17. Sarode SC, Sarode GS. Identification of cell cannibalism in oral squamous cell carcinoma with clinico-pathological correlation. Oral Oncol 2013; 49: S90-1.

18. Jose D, Mane DR, Datar U, et al. Evaluation of cannibalistic cells: a novel entity in prediction of aggressive nature of oral squamous cell carcinoma. Acta Odontol Scand 2014; 72: 418-23.

19. Sarode GS, Sarode SC, Karmarkar S. Complex cannibalism: an unusual finding in oral squamous cell carcinoma. Oral Oncol 2012; 48: e4-6.

20. Bauchwitz MA. The bird's eye cell: cannibalism or abnormal division of tumor cells. Acta Cytol Abstr 1981; 25: 92.

21. Brouwer M, de Ley L, Feltkamp CA, et al. Serum-dependent "cannibalism" and autodestruction in cultures of human small cell carcinoma of the lung. Cancer Res 1984; 44: 2947-51.

22. Chi L, Vogel JE, Shelokov A. Selective phagocytosis of nucleated erythrocytes by cytotoxic amoebae in cell culture. Science 1959; 130: 1763.

23. Monteagudo C, Jorda E, Carda C, et al. Erythrophagocytic tumour cells in melanoma and squamous cell carcinoma of the skin. Histopathology 1997; 31: 367-73.

24. Alfarouk KO, Muddathir AK, Shayoub ME. Tumor acidity as evolutionary spite. Cancers (Basel) 2011; 3: 408-14.

25. Lessi E, Marino ML, Lozupone F, et al. Tumor acidity and malignancy: novel aspects in the design of anti-tumor therapy. Cancer Ther 2008; 6: 55-66.

26. Kale A. Cellular cannibalism. J Oral Maxillofac Pathol 2015; 19: 7-9.

27. Klionsky DJ. Cell biology: regulated self-cannibalism. Nature 2004; 431: 31-2.

28. Ohsaki H, Haba R, Matsunaga T, et al. "Cannibalism" (cell phagocytosis) does not differentiate reactive renal tubular cells from urothelial carcinoma cells. Cytopathology 2009; 20: 224-30.

29. Barresi V, Branca G, Ieni A, et al. Phagocytosis (cannibalism) of apoptotic neutrophils by tumor cells in gastric micropapillary carcinomas. World J Gastroenterol 2015; 21: $5548-54$.

30. Krajcovic M, Overholtzer M. Mechanisms of ploidy increase in human cancers: a new role for cell cannibalism. Cancer Res 2012; 72: 1596-601.

31. Bergsmedh A, Szeles A, Henriksson M, et al. Horizontal transfer of oncogenes by uptake of apoptotic bodies. Proc Natl Acad Sci USA 2001; 98: 6407-11. 